\title{
Evaluation of Centrally Oriented Measures of Education by Project
}

\section{Evaluación de la enseñanza por proyectos de las medidas de tendencia central}

\author{
Ángela Torres-Parra (C) \\ Institución Educativa Técnica Francisco José de Caldas, Boyacá, Colombia \\ Adriana Granados-Comba (D) \\ Universidad Pedagógica y Tecnológica de Colombia, Tunja, Colombia \\ Maryluz Castro-Moreno (D) \\ Universidad Pedagógica y Tecnológica de Colombia, Tunja, Colombia
}

\begin{abstract}
Objective: this investigation aimed to assess the impact of applying project-based pedagogy to the topic of central trend measures and statistical graphs. Method: the study's participants comprised ninth-grade students of the Technical Educational Institution Francisco José de Caldas and were divided into two groups: experimental and control. The quasi-experimental design of the study involved three stages: diagnostic groundwork, a six-phase action plan construction, and transformation. Pre- and post- tests were conducted to measure research outcomes. Results: students assigned to the experimental group evinced an improvement in the comprehension of the addressed topics and a significant increase was observed in their communication and problem-solving skills. Discussion and Conclusions: the application of the pedagogic strategy of problem-based learning to measures of central tendency and statistical graphics encouraged students placed in the experimental group to discover statistical answers that would assist them in their daily personal and environmental requirements. It also ameliorated their conceptual comprehension and interpretation, improved their communication abilities and problem-solving skills, strengthened teamwork, and increased their sense of responsibility in comparison to the traditionally taught class.
\end{abstract}

Keywords: project, learning, context, statistics, graphs.

\section{Resumen}

Objetivo: evaluar la incidencia de la enseñanza por proyectos en el proceso de aprendizaje de las medidas de tendencia central y gráficos estadísticos. Método: se trabajó bajo un diseño cuasi experimental, con dos grupos: experimental y control en estudiantes del grado noveno de la Institución Educativa Técnica Francisco José de Caldas, aplicando un pre test y post test, recurriendo a tres etapas: preparación diagnóstica, construcción del plan de acción (compuesta por seis fases) y transformación. Resultados: se evidenció mejora en la comprensión de las temáticas abordadas y aumento significativo en las competencias comunicativas y de resolución de problemas en los estudiantes de grupo experimenta. Discusión y Conclusiones: la implementación de la estrategia didáctica aprendizaje basado en problemas para la enseñanza y aprendizaje de las medidas de tendencia central y gráficos estadísticos, desarrolló una estadística como respuesta o ayuda a las necesidades del estudiante y su entorno, que facilitó la interpretación y comprensión de los conceptos en un mayor grado, respecto a una clase tradicional, además permitió mejorar el desempeño de los estudiantes en las competencias comunicativas y de resolución de problemas, así como el fortalecimiento de habilidades en trabajo en equipo y responsabilidad.

Palabras clave: aprendizaje, proyectos, contexto, gráficos, estadística.
Open Access:

ISSN: 0124-2121

E-ISSN: $2665-2420$

REVIEW ARTICLE

Copyright (C)

By Educación y Humanismo

Editor:

Dhayana Fernández Matos

Universidad Simón Bolívar

Correspondence:

Adriana Granados adriana.granados@uptc.edu.

co

Received:26-05-2020 Accepted: 20-07-2020 Online from: 09-09-2020

DOI:

10.17081/eduhum.22.39.4161 


\section{Introduction}

The Ministry of National Education (MNE) has issued several significant guidelines over the years: Estándares básicos de competencias en matemáticas (MEN, 2006), Lineamientos Curriculares de Matemáticas (MEN, 1998) and Derechos Básicos de Aprendizaje-DBA (MEN, 2016), [Basic Standards of Competencies in Mathematics (MEN, 2006), the Curricular Guidelines of Mathematics (MEN, 1998) and the Basic Rights of Learning-DBA (MEN, 2016). These documents seek to establish random thinking and data systems as indispensable conceptual constructs for the inculcation of mathematical competencies. The ministry thus proposes to encourage the practical use of everyday situations to promote the comprehension of mathematical concepts, assist in their development, and facilitate their actuation so that learners can make appropriate decisions by accomplishing adequate analyses of data-sets.

In this context, the teaching of statistics represents the classroom construction of useful and important knowledge that can easily be applied to the real world (MEN, 2006). The current educational framework of the Institutional Educational Project requires viable pedagogical environments to be implemented to enable students to apprehend and articulate classroom-constructed knowledge in their daily sociocultural, family, and work environments.

The recommendation regarding the development of random thinking and data systems involves working with students on applied statistics (MEN, 2006) ${ }^{b}$ to enable them to examine their situations and make decisions based on data-set analyses. Thus, researchers like Batanero y Díaz (2011) have contended that the teaching of statistics must transcend tedious equations, algorithms, and calculations that merely cause erroneous intuitions of this science. Such scholars emphasize that:

These intuitions are not corrected with an involved expository teaching, nor with the exercise in the calculation or in the resolution of routine problems, so it is necessary that the introduction of statistics in schools be accompanied by a renewal of teaching methods so that it becomes really affective. (p. 31).

On the other hand, the academic performance of the first semester revealed certain shortcomings and difficulties in the ninth-grade students' process of learning statistics at the educational institution being studied, especially with regard to the comprehension of measures of central tendency and the interpretation of some statistical graphs (Reporte Sistema Integral de evaluación Tecnicaldas, 2019). Moreover, the historical records of the ninth-grade knowledge examination results from 2017 (Report by school 2017, results test to know 9, IE Técnica Francisco José de Caldas) conducted by the Instituto Colombiano para el Fomento de la Educación Superior- Icfes (Icfes, 2014) evidenced that $56 \%$ of the student population did not recognize the average, median, and mode of a data-set. In addition, $67 \%$ of the students exhibited a flawed understanding of the relationships between different representations of statistical data. Thus, most students could not 
analyze the relevance of a given representation, formulate inferences, demonstrate their reasoning, or make deductions based on their assessment of the provided information.

The current investigation was proposed in view of the above facts, to evaluate the impact of Project-Based Learning (PBL) on the processes applied by ninth-grade students to the understanding of the topic of central trend measures and statistical graphs. PBL is a longstanding experiential teaching methodology that has recently regained scholarly interest (Casal \& Mora, 2019). According to Muñoz \& Gómez (2017), projects indicate a type of classroom-based work that encourages students to inquire into topics based on questions they regard as useful and important and that, in some cases, emanate from them.

For Gutiérrez (2017), however, PBL is a learning model that requires students to plan, implement, and evaluate tasks applicable to the real world beyond the classroom, making education a contextual setting for problem-solving. Some of the principal characteristics of PBL that make the construction of knowledge possible include the comprehensiveness of a problem; the need for research to resolve it; collaborative work; the union of reality and schooling; the connection between students, teachers, family, and environment; the roles performed by learners; and the motivation of the instructors (Balcells, 2014; Constantinou \& Nicolaou, 2018; Lepe \& Jiménez, 2014; Rodríguez \& Vílchez, 2015).

The PBL methodology has been utilized to good effect in the basic and applied sciences and has contributed substantially to the development of skills and competencies in students, who become active participants and contributors to their learning (Rodríguez 2016; García, Coronado, \& Giraldo 2017).

In their article, Carrasco \& Rodríguez (2015) recommend the involvement of investigative situations relevant and proximate to the environments of the learners, to promote the understanding of statistical concepts and thereby stimulate the development of statistical literacy, statistical thinking, and statistical reasoning.

Siswono, Hartono, and Kohar's study (2018) highlights the effectiveness of PBL in teaching statistical concepts and demonstrates results that evince significant improvement in the conceptual grasp of students via their methods in comparison to traditional pedagogy. They conclude, therefore, that PBL allows knowledge to be imbibed through the interactions of discrete environmental elements, empowering competencies from being, learning, and doing.

In another context, scholarly investigations involving information and communication technologies (ICT) have advanced in recent years because of their influence on the learning process. Real (2011) asserts that ICT can be pivotal to the teaching and learning of mathematics because of its congruence with the preferences and interests of students. Barrera's study (2017) is notable for the particular case of strengthening competencies in statistics (MEN, 2006, p.49), reporting significant improvement in statistical skills as well as teamwork through the application of collaborative projects mediated by ICT to stimulate statistical learning. 
Numerous other authors both in the international arena such as Arteaga \& Batanero (2018); Cordovi, Valenciano, Pruna, Murguencia \& Antúnez (2018); Peña \& Acosta (2017) Aguirre \& Alcaraz (2016); Ruíz (2015), Espinoza \& Sánchez (2014) and in the national domain such as Cano, Gómez \& Álvarez (2015); Londoño (2017), Fonseca (2014), Pacheco, Parra \& Vargas, (2015), Melo (2017), Barrera, Morales \& Duarte (2017) and Salcedo (2018) have also proposed and conducted PBL studies involving collaborative work and ICT.

\section{Methodology}

The methodology employed to conduct the current research initiative encompassed two aspects: the investigative approach and the technique applied for the study.

\section{Research Approach}

The quantitative approach was utilized for the current investigation because it allowed the measurement of the significance of the impact of PBL on communicative skills, problem-solving, reasoning, as well as random thinking. A preliminary concept test and a final test were used as the mechanism of data collection and the analysis purposed to determine the veracity of the hypothesis, establish behavior patterns, and ascertain the degree of significance of the variables. Hernández, Fernández, and Baptista (2014) have stated that established processes set according to certain logical rules must be rigorously followed in quantitative studies. Additionally, the generated data must pass standards of validity and reliability and the lessons learned should contribute to knowledge generation.

\section{Investigative Technique}

The study was quasi-experimental because the selected educational institution incorporated two ninth-grade sections, each with 34 students who belonged mostly to the rural areas of the municipality with roads that were difficult to access and limited or sometimes non-existent Internet connectivity. According to Hernández, Fernández, and Baptista (2014), subjects are not randomly assigned to the groups nor paired in studies that apply the quasi-experimental design. Instead, the intact groups are already formed before the experiment is conducted.

Quasi-experimental designs lack experimental control of all variables due to the absence of randomization in the selection of subjects as well as in the assignment of subjects to experimental or control groups. Hence, an initial test is usually included to confirm equivalence between groups.

In the current case, the groups were labeled $9 \mathrm{~A}$ and $9 \mathrm{~B}$ and an initial test was administered to students from both groups. Based on the results of this pre-test, 9B became the control group and $9 \mathrm{~A}$ was selected as the experimental group on which the proposed PBL strategy was applied. The elaboration and development of the projects with this latter group allowed students to interact with knowledge and context in three stages: 
The first stage of diagnostic preparation or reflection encompassed the identification of fundamental concepts relating to descriptive measures and statistical graphs along with a review of the extant literature on learning, methodology, project-based evaluation (Cobb, 1992), and the role of statistics in educational research.

The second stage incorporated the construction of the action plan involving PBL for the learning of measures of central tendency and the interpretation of some statistical graphs through the following phases:

- Phase 1: Students were organized in workgroups of six members, each with a defined role taking into account the level of performance presented during previous academic periods. Thus, each group represented members superior, high, average, and low performance to encourage peer learning.

- Phase 2: Each group selected a theme suited to the interests of its six members in the context of the overall theme. They generated appropriate in-group discussions, proposed topics of interest, and socialized their peers and teachers to their chosen topics highlighting the importance and impact of the statistical research and analysis of their selected themes.

- Phase 3: The students posed problematizing questions and began creating the presentation document on their topic according to the American Psychological Association style standards.

- Phase 4: The resources for the study were selected for students to obtain the necessary information, the population and/or sample was identified through readings, video viewing, and quiz development through the Khan Academy platform for the administration of previously designed surveys and interviews.

- Phase 5: Previous knowledge and newly acquired concepts were employed to accomplish the collection and analysis of data. The research proposed by the working groups required the conceptualization of the nature of the data to be compiled and necessitated the application of appropriate statistical techniques for the evaluation of the obtained data.

- Phase 6: Each group produced a final report of its achieved results and socialized its outcomes.

Finally, the third stage of transformation was devoted to the systematization of the learning experience and the presentation of results. Each group prepared a final report and achieved the socialization of its results through oral support. Subsequently, the students took their final test to demonstrate the effects of the experiment by summarizing the measures of central tendency. 


\section{Instruments}

The study data were collected via two tests: a pre-investigation examination of previously acquired concepts and the post-experiment final examination whose analysis categories were based on the basic competencies of mathematical education as oriented by the MNE. In turn, these tests were evaluated by an expert to verify their authority.

\section{Testing of Previously Acquired Concepts}

The pre-test was structured according to the programmatic content of the basic guidelines and standards set for national education by the Ministry of Education (2006). It was designed to evaluate the students' level of communication skills, reasoning, and statistical problem-solving. It incorporated ten items, eight multiple selection questions, and two open questions adapted from the knowledge test applied in 2016 to ninth-grade students. Additional validation was achieved through expert evaluation. A maximum score of 100 points and a minimum score of ten points could be achieved on this test in accordance with the Comprehensive Evaluation System of the educational institution being studied.

\section{Figure 1.}

Presents examples of questions asked in the pre-test

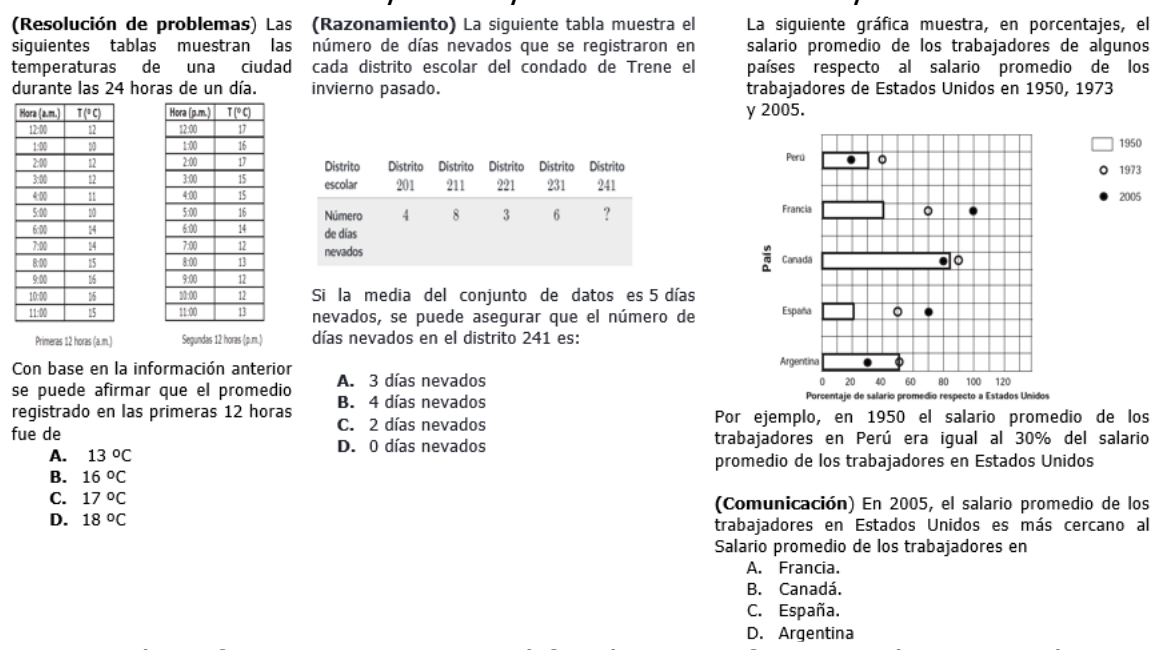

Note: Examples of questions proposed for the test of previously acquired concepts.

\section{Final Test}

This post-experiment test was adjusted to ninth-grade knowledge expectancies and comprised 15 items: 13 multiple-choice and two open questions that queried discrete competencies, communication, reasoning, and problem-solving. A maximum score of 100 points and a minimum of ten points could be scored on this test in accordance with the policies of the educational institution under study. 
Figure 2.

Presents examples of questions asked in this test

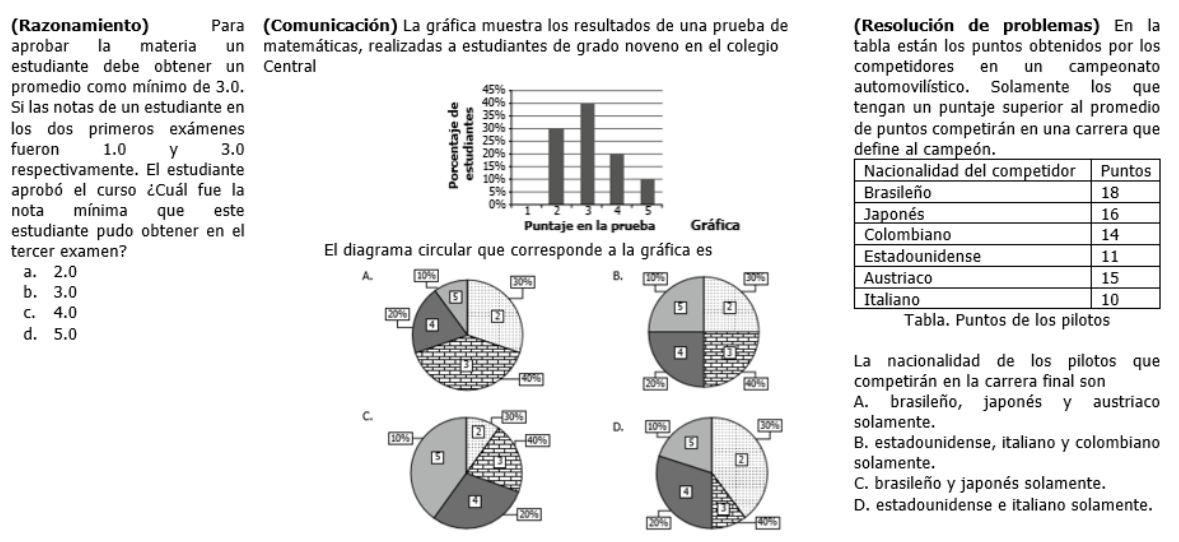

Note: Examples of questions included in the final test.

\section{Analysis Categories}

The competencies of communication, reasoning, and problem-solving grounded in standards of national education were applied to the analysis of the results obtained through the implementation of the tests. A brief description of these competencies follows.

The competence of reasoning relates to an individual's ability to account for the how and why of the paths followed to achieve conclusions, to justify strategies and procedures actioned for the handling of problem situations. It helps people to formulate hypotheses, make conjectures, explore examples and counterexamples, test and structure arguments, generalize properties and relationships, identify patterns, express them mathematically, pose questions, recognize different types of reasoning, and distinguish and evaluate chains of arguments.

Communication competence refers to a person's ability to articulate ideas, interpret, use different types of representation, and describe mathematical relationships. It helps people describe situations or problems using written language or use concrete, pictorial, graphic, and algebraic notations to manipulate symbolic expressions and formulas, use variables, and describe strings of oral and written arguments. It facilitates the translation, interpretation, and distinction between different types of representations, the discernment of formal and symbolic language, and the transcription of ideas from natural language to formal symbolic inscriptions, and vice versa.

The competence of problem-solving indicates the human ability to formulate conundrums from situations confronted within and outside mathematics, to develop and apply discrete strategies for the resolution of such conceived difficulties, to justify the choice of problem-solving methods and instruments, to validate the relevance of accurate or approximate calculations for the solution of problems, to assert the reasonableness or otherwise of an obtained response, to verify and interpret results in light of the original 
problem, and to generalize solutions and strategies to facilitate the handling of new problem situations.

\section{Analysis Techniques}

The Shapiro-Wilk test was utilized to accomplish the comparison of the means of the obtained scores. The application of this test in the present instance enabled the determination of the normal distribution and its assertion with a confidence value of $95 \%$. According to the probability result ( $p$-valor), if $p(W) \geq 0,05$ the null hypothesis was validated and if $p(W)<0,05$ the null hypothesis was rejected (López-Roldán \& Fachelli, 2016).

Non-parametric tests were usedif results did not follow a normal distribution. For example, the appropriate Mann-Whitney test was applied when the assumptions on which the test was based $t$ (normality and homogeneity) were not met. (Pérez et al., 2009). The null hypothesis was rejected if the $p-$ value $<0.05$.

The R Commander (Rcmdr) package containing the statistical software R 3.6.1 was utilized for data analysis.

\section{Results}

The initial analysis of data employed univariate and bivariate descriptive statistical techniques. It was followed by a comparison of means to identify the efficacy of the PBL strategy on the basis of the results obtained from the analysis of the pre-test and final test data-sets. The level of assessed skill was also considered for the comparison. This analysis was performed using the R 3.6.1., statistical package.

\section{Student Profile}

Students of the ninth grade formed the target population of this study, which was conducted on 68 students of whom $62.7 \%$ were women. The average age of the participants was 15 years and $65 \%$ of the population were rural residents with limited Internet availability and hard-to-access routes to their homes. The majority of the participants' parents (61.5\%) were educated only at the primary level and only $9.3 \%$ of the parents were professionals. This result indicated that the parents of most students were unable to effectively supplement the classroom-based instruction of curricular topics, potentially affecting the student's academic performance. Such an apprehension was confirmed by the low statistics scores presented in the school's record of assessments. The PBL strategy was thus postulated to become a pedagogic resource that would improve the students' understanding of subjects that posed major difficulties.

\section{Results of the Test of Previously Acquired Concepts}

Both sections of the ninth grade, $9 \mathrm{~A}$ and $9 \mathrm{~B}$, were administered this test. The results and analyses of the scores obtained by the students are presented below. 
Table 1 shows the central trend and dispersion measurements for the scores obtained in the test of previously acquired concepts. The analysis revealed that $50 \%$ of $9 \mathrm{~A}$ students scored 55 points or less in this test, while $50 \%$ of $9 B$ students scored 65 points or less. In addition, $75 \%$ of $9 \mathrm{~A}$ students earned less than 70 points. These scores indicated that both groups evinced basic or low performance on this test according to the institution's evaluation criteria adjusted to the MNE curricular guidelines.

Table 1.

Analysis of the test of previous concepts $9 A-9 B$

\begin{tabular}{cccccccc}
\hline Grade & Mean & Median & Mode & Standard deviation & Q1 & Q2 & Q3 \\
\hline 9A & 57.79 & 55 & 50 & 15.87 & 50 & 55 & 70 \\
9B & 63.59 & 65 & 60 & 19.44 & 55 & 65 & 70 \\
\hline
\end{tabular}

Source: Primary data collected for the reported study

Table 2 presents the results obtained for the individual dimensions of the test. The students of section 9A obtained an average of 50 points in communication with a standard deviation of 26.74 points. Their obtained scores also evinced high dispersion. Further, $75 \%$ of the $9 \mathrm{~A}$ students were marked 60 points or less, signifying a basic and/or low-level performance on this aspect of the test. On the other hand, 9B students achieved an average of 57 points in the same measure with a standard deviation of 20.02 points, and $75 \%$ of $9 B$ students received at least 62 points.

Table 2.

Performance analysis by competence

\begin{tabular}{clccccccc}
\hline Grade & Skill & Mean & Median & Mode & Standard deviation & Q1 & Q2 & Q3 \\
\hline \multirow{2}{*}{ 9A } & Communication & 50 & 46.17 & 60 & 26.74 & 10 & 46.17 & 60 \\
& Resolving & 45.29 & 60 & 60 & 26.54 & 10 & 60 & 60 \\
& Reasoning & 45 & 43.52 & 60 & 28.37 & 10 & 43.52 & 60 \\
\hline \multirow{2}{*}{ 9B } & Communication & 57 & 52.14 & 62 & 20.02 & 12 & 52.14 & 62 \\
& Resolving & 48.3 & 58 & 62 & 22.13 & 12 & 58 & 62 \\
& Reasoning & 46 & 45.71 & 62 & 23.51 & 12 & 45.17 & 62 \\
\hline
\end{tabular}

Source: Primary data collected for the reported study

Similarly, the results of the testing of the competence of problem-solving revealed that $75 \%$ of $9 \mathrm{~A}$ students registered a low performance, attaining a maximum rating of 60 points. On average, 9A students were accorded a competency rating of 46.17 points with a standard deviation of 26.54 points with regard to problem-solving. In the reasoning aspect, $50 \%$ of the $9 \mathrm{~A}$ students were assessed at 43.52 points or fewer, evidencing their difficulties with the analysis and solution of problems.

The results of the test of previously acquired concepts thus prove that students were deficient in their conceptual comprehension of the measures of central tendency and the interpretation of statistical graphs as assessed through the skills described above. 
Therefore, there was an evident need for appropriate strategies that could improve their learning process, contribute to the amelioration of their results in the standardized ninthgrade tests such as Pruebas Saber, and also facilitate the overall enhancement of their academic performance. Hence, the implementation of PBL was proposed through the above-mentioned phases.

The results displayed in Tables 1 and 2 evinced lower average scores for 9A in the test of previously acquired concepts. Thus, this section was selected as the experimental group, while $9 \mathrm{~B}$ was designated as the control group.

The PBL pedagogic strategy was subsequently implemented with 9A and its outcomes were evaluated through an established assessment rubric (Masmitja, 2013). The outcomes incorporated the students' elaboration of the group projects, the execution of the projects, and the performance of each workgroup. These results are described below.

\section{Group 1: Healthy lifestyles in primary school students}

\section{Performance level: Superior}

This workgroup was characterized by its organization, sense of responsibility, and adherence to deadlines. The group delivered the requisite activities on established dates and took initial patterns into account. The project-outcomes disclosed that about $70 \%$ of students enter the educational system with good eating habits (preschool). However, only around $40 \%$ continue these healthy habits at the end of primary schooling (grade five). This study specifically mentioned habits relating to the daily consumption of fruits and water, hygiene practices (e.g., hand washing), and the low consumption of packaged or junk food. Further, only 25 percent of the school population was found to consume five meals a day and 75 percent ate breakfast with ample time to enjoy the food.

Group 2: Factors influencing the academic performance of ninth-grade students in mathematics and Spanish Tecnicaldas.

\section{Performance level: Superior}

This workgroup exhibited excellent organization in its development of the project, demonstrated teamwork in fully fulfilling each feature of the established parameters and requested activities. It found that $50 \%$ of ninth-grade students spend 30 minutes or less per day studying subjects such as Spanish, mathematics, and English. On the other hand, around $75 \%$ of ninth-grade students present a basic or low cumulative performance (I semester, 2019) with respect to their English assessment. Among factors that influence the academic performance of ninth-grade students in Spanish, mathematics, and English, it was notable to discover that $75 \%$ of the learners do not dedicate adequate time to extracurricular activities and that they professed scant interest to the study of these subjects. 


\section{Group 3: The culture of recycling in the Socotá municipality}

\section{Performance level: Superior}

This workgroup fulfilled all its established activities as per the established timetable and demonstrated competent group communication and teamwork. Its study disclosed that around $50 \%$ of the districts in the municipality of Socotá are unaware of the correct methods of recycling. In fact, $75 \%$ of the inhabitants of this municipality claim to recycle only when the sanitation system does not receive their waste. Finally, less than $50 \%$ of this population conserves water or electricity because of a general lack of awareness of the importance of recycling and reuse.

\section{Group 4: Alcohol consumption in the town center of Socotá municipality}

\section{Performance level: High}

This group did not meet set deadlines on some of its final activities because of internal difficulties (the education system leader retired). However, it met the requirements of the socialization of its work, concluding that 80 baskets of beer, five bottles of whiskey, and 25 bottles of artisanal brandy are sold on average in the town center over the weekend. $A$ male resident of Socotá visits a liquor store thrice on average over the weekend time-off from work. Also, the favorite drink for family celebrations in this municipality is homemade brandy because it is inexpensive and easily available.

\section{Group 5: The leisure activities enjoyed by Tecnicaldas basic education students}

\section{Performance level: High}

The performance of this group was marked "high" only because it missed the set deadline for the socialization of its activities. At the end of the project, this group concluded that around 75 percent of the school's students do not engage in leisure-time activities. Also, $50 \%$ of the students do not spend their free time playing sports, visiting the library, or engaging in self-development through extracurricular activities. On weekends, $85 \%$ of the students prefer spending their leisure hours on online social networks or meeting friends on the streets rather than engaging in some form of recreational activity.

Group 6: The use and care of natural resources in La Vega, in the municipality of Socotá

\section{Performance level: High}

The research topic selected by this group lacked depth and members evinced unequal participation in the development and execution of group activities. This study concluded that residents of the area displayed little care for the preservation of native species (trees 
in the zone); that $75 \%$ of pavement dwellers contemplate the felling of trees to be an activity that would generate economic resources without affecting the ecosystem. Further, less than half the inhabitants of these areas displayed any care for water sources because they understood the importance of water conservation.

The final test was administered after the PBL strategy was implemented with section 9A. Subsequently, the results obtained by $9 \mathrm{~A}$ and $9 \mathrm{~B}$ were compared using statistical techniques to identify whether any significant differences could be observed vis-à-vis the traditional pedagogy after PBL was accomplished. The results of the final test are presented in Table 3.

Table 3.

Final test results obtained by $9 A$ and $9 B$

\begin{tabular}{ccccc}
\hline Grade & Mean & $\begin{array}{c}\text { Standard } \\
\text { Deviation }\end{array}$ & $\begin{array}{c}\text { Supposed Test of Normality } \\
p \text {-value }\end{array}$ & $\begin{array}{c}\text { Mann-Whitney Test } p \text { - } \\
\text { value }\end{array}$ \\
\hline $9 \mathrm{~A}$ & 70 & 13.55 & 0.0568 & 0.0000033 \\
$9 \mathrm{~B}$ & 65 & 17 & 0.0070 & 0.0000075 \\
\hline
\end{tabular}

Source: Primary data collected for the reported study

These outcomes show that 9A students earned 70 points on average in the final test with a standard deviation of 13.55 points, while the students of $9 B$ averaged 65 points with a standard deviation of 17 points. A comparison of averages was then performed to determine whether the differences between the averages were significant.

The Shapiro-Wilk test was applied for the comparison of the averages of the scores obtained by $9 \mathrm{~A}$ and $9 \mathrm{~B}$ in the final test based on a $95 \%$ confidence value. The following hypotheses were formulated for the normal distribution of the data obtained after the final test:

$H_{0}$ : Thedistributionisnormalf. a $H_{a}$ : Distributionisnotnormal.

According to the probability result ( $p-$ valor), if $p(W) \geq 0,05$ the null hypothesis was validated and if $p(W)<0,05$ the null hypothesis was rejected (López-Roldán \& Fachelli, 2016).

The assumptions of normality and homogeneity were tested to conduct the comparison of averages. The following hypotheses were proposed for the normality assumption of the variable final test scores attained by $9 \mathrm{~A}$ and $9 \mathrm{~B}$ :

$$
\begin{gathered}
H_{0}=\text { the final test score variable displays a normal distribution vs } \\
H_{a}=\text { the final test score variable does not display a normal distribution }
\end{gathered}
$$

The Shapiro-Wilk test for the hypothesis system with a 95\% confidence level evidenced that the final test score variable did not present a normal distribution for 9B with ap value $<0.05$; therefore, the null hypothesis was rejected and it became necessary to use 
a non-parametric test for the independent samples.

The appropriate Mann-Whitney test is a non-parametric test applied when the assumptions on which the t-test is based (normality and homogeneity) are not met (Pérez et al., 2009). If the $p$-value $<0.05$, the null hypothesis is rejected. For the current study, the posited hypotheses were:

$H_{0}$ : There are no differences in the variable final test scores between the students of $9 A$ and $9 B$.

The $\mathrm{R}$ Commander package (Rcmdr) containing the statistical software $\mathrm{R}$ 3.6.1 was employed to calculate the Mann-Whitney test. The scores obtained in the final test for $9 \mathrm{~A}$ and $9 \mathrm{~B}$ achieved the significance level of $95 \%$, the null hypothesis was thus rejected and there was inadequate statistical evidence to indicate the absence of differences between students of $9 \mathrm{~A}$ and $9 \mathrm{~B}$ in the final test score variables as their $p-$ valor $\leq 0.05$

It was therefore concluded that the application of the PBL strategy resulted in significant improvement in the learning of measures of central tendency and in the students' interpretation of some statistical graphs.

\section{Discussion and conclusions}

The results of this investigation suggest that the usefulness of the traditional methodology in the classroom should be reevaluated and reoriented because it does not encourage satisfactory academic performance by the students as demonstrated by the scores obtained by the students in the test of previously acquired concepts in comparison to the outcomes of the final test results of the experimental group. The comparison of means for the competencies evaluated in the initial and final test achieved the $95 \%$ level of significance which made it possible to conclude that the PBL strategy improved results significantly in communicative and problem-solving competencies with $p-$ value $<0.05$

It was thus evidenced that the implementation of pedagogic methods based on PBL was efficacious for the teaching and learning of the measures of central tendency and statistical graphs in the ninth grade of Tecnicaldas. The overall performance of students in the experimental group was enhanced by 12.5 points on average in comparison to the initial test. Thus, a performance amelioration was also observed in the statistical skills of the students of the experimental group, who showed a 10-point increase on average in scores of communicative competence; a 14.71 point enhancement in the problem-solving element; and a 15-point improvement in reasoning skills.

It can thus be claimed that as a learning strategy, PBL favors the development of critical thinking and empowers mathematical and sociable logical skills by allowing students to work collaboratively in groups to envision projects, freely identifying problems, establishing analysis strategies, conceiving of possible solutions, arriving at potential 
conclusions, and utilizing statistical concepts. In this manner, students demonstrate the usefulness of curricular topics taught in classrooms and develop the discrete skills needed in the school environment. Arteaga and Batanero (2018) and Cordovi et al. (2018); corroborate the effectiveness of the PBL vis-à-vis the traditional methodology in the creation of environments that favor learning and in the improvement of the learners' apprehension of given topics.

Similarly, PBL generated a new dynamic in the classroom in the current study. Students were able to utilize distinct approaches and strategies to ask, define, debate, and establish action plans toward the achievement of a goal, using the knowledge acquired in the classroom and individual tools attained through the development of their project, as Arteaga and Batanero have iterated (2018):

Work with projects develops new skills, since understanding, interpreting and reacting to statistical information requires not only statistical or mathematical knowledge, but also linguistic skills, knowledge of the context, ability to pose questions, and a critical stance that is supported by a set of beliefs and attitudes, which are developed in the project (p. 1411)

It is also noteworthy that PBL enhanced the investigative spirit of students through its emphasis on oral and written expression as well as teamwork. This outcome is congruent with the assertion of Peña and Acosta (2017), who claim that students become researchers, solve problems, are creative, and strengthen their teamwork skills through PBL. Further, the actions and interactions of students with their environment enable them to link this collaborative work to the realities of their existence. Thus, PBL helps learners to intensify their understanding of important issues and to improve relationships with their colleagues by encouraging discourse and tolerance in the face of challenging differences.

PBL ameliorates the classroom environment. This improvement may be showcased through changes in learner attitudes and dispositions toward a particular subject because PBL allows room for doubts that may arise as a project is developed. Problems encountered by students can be resolved by the teacher or by colleagues, and the removal of conceptual obstacles need not be tedious because the concepts contribute to the defined project and the significance of their resolution is thus recognized. The study conducted by Barrera, Morales, and Duarte (2017) is thus corroborated (De la CalleCarracedo, 2016; Londoño, 2017; Aguirre \& Alcaraz, 2016): PBL promotes active learning and allows the development of transferable skills such as teamwork, collaborative learning, or effective communication to be introduced into the process with relative ease through the analysis of real data.

As a pedagogy, PBL can enrich the integral and holistic development of students, consolidating the desired statistical literacy in each learner so that citizens of the world can utilize these concepts in myriad real contexts. The study conducted by Rodríguez and 
Vílchez (2015), reported that PBL develops analytical skills not readily available through traditional learning and applicable to conceptual mathematical problems.

It is finally asserted that this study applied PBL in the context of a population with extremely limited access to new technologies and accustomed to traditional pedagogy. The existing environment of the students enabled them to become more motivated by PBL and facilitated the improvement of their communication as well as cognitive competencies within and outside the classroom. Numerous scholars have endorsed this opinion (Rodríguez \& Vílchez, 2015; Salcedo, 2018; Fonseca, 2014; Pacheco, Parra \& Vargas, 2015; Melo, 2017; and Barrera, Morales \& Duarte, 2017) and have claimed multiple benefits of PBL with regard to the development and empowerment of critical and creative thinking, the improvement of attitudes toward learning, and peer education.

\section{Referencias}

Arteaga, P., y Batanero, C. (2018). Enseñanza de la estadística con proyectos y comprensión gráfica. Propuestas para la enseñanza de las matemáticas, 31(2), 1410-1416.

http://scholar.googleusercontent.com/scholar?q=cache:vYIJY8bGjpIJ:scholar.googl e.com/+Batanero, +C., +\%26+Arteaga, +P.+(2018).+Ense\%C3\%B1anza+de+la+es tad\%C3\%ADstica+con+proyectos+y+comprensi\%C3\%B3n+gr\%C3\%A1fica.\&hl=e s\&as_sdt=0,5\&as_vis $=1$

Aguirre, J. A., y Alcaraz, A. B. (2016). El aprendizaje de la estadística a través de PBL con futuros profesores de Primaria. Contextos Educativos. Revista de Educación, (1), 31-43.

https://publicaciones.unirioja.es/ojs/index.php/contextos/article/view/2699/2678

Balcells, M. (2014). El trabajo por proyectos: Una metodología global. Cuadernos de Pedagogía, (450), 7-13.

Barrera, M., Fernández, F., y Duarte, J. (2017). Aprendizaje basado en proyectos Colaborativos. Mediados por TIC para el desarrollo de competencias en estadística. $\begin{array}{llll}\text { Saber, } \quad \text { ciencia libertad 220-232. } & \text { 12(2), }\end{array}$ https://revistas.unilibre.edu.co/index.php/saber/article/view/1590/1175

Barrera, M. (2017). Aprendizaje basado en proyectos colaborativos mediados por tic para el desarrollo de competencias en estadística. [Tesis de maestría, Universidad Pedagógica y Tecnológica de Colombia, Duitama, Colombia].

Batanero, C., y Díaz, C. (2011). Estadística con proyectos. https://www.ugr.es/ batanero/pages/ARTICULOS/Libroproyectos.pdf 
Cano, M., Gómez, J., y Álvarez, I. (2015). Propuesta didáctica para abordar la interpretación y cálculo de las medidas de tendencia central. III Encuentro Internacional de Matemáticas, Estadística $\mathrm{Y}$ Educación Matemática. http://funes.uniandes.edu.co/10528/1/Cano2015Propuesta.pdf

Carrasco, J., y Rodríguez, J. (2015), Enseñanza de la Estadística en contexto: Análisis e interpretación de datos oficiales, XIV Conferencia Interamericana de Educación Matemática, Chiapas, México. http://xiv.ciaemredumate.org/index.php/xiv_ciaem/xiv_ciaem/paper/viewFile/979/404

Casal, J. D., Lope, S., y Mora, L. (2019). Qué proyectos STEM diseña y qué dificultades expresa el profesorado de secundaria sobre Aprendizaje Basado en Proyectos. Revista Eureka sobre Enseñanza y Divulgación de las Ciencias, 16(2), 220301-220316. https://revistas.uca.es/index.php/eureka/article/view/4762

Cobb, G. (1992). Teaching Statistic. En L. Steen (Editor), Heeding the Call for Change (pág.14-54). United States: Mathematical Association of America. http://www.statlit.org/pdf/1992-Steen-MAA-Heeding-Call-For-Change.pdf

Constantinou, C. S., \& Nicolaou, S. A. (2018). Motivation, Challenges, Support (MCS) Cycle Model for the Development of PBL Tutors. Qualitative Research in Education, 71 , 1-35. https://hipatiapress.com/hpjournals/index.php/qre/article/view/3064

Cordovi, V., Valenciano, V., Pruna, L., Murguencia, A., y Antúnez, J. (2018). Aprendizaje de las medidas de tendencia central a través de la herramienta EXeLearning. MEDISAN, 22(3),258-265. https://www.medigraphic.com/pdfs/medisan/mds2018/mds183f.pdf

De la Calle-Carracedo, M. (2016). Aprendizaje basado en proyectos (ABP): Posibilidades y perspectivas en ciencias. Íber: didáctica de las ciencias sociales, geografía e historia, (82), 7-12. https://dialnet.unirioja.es/servlet/articulo?codigo=5529313

Espinoza, C., y Sánchez. (2014). Aprendizaje Basado en problemas para enseñar y aprender estadística y Probabilidad. Paradigma, 35(1),103-128. http://ve.scielo.org/pdf/pdg/v35n1/art05.pdf

Fonseca, A. (2014). Propuesta de enseñanza- aprendizaje de la Estadística, a través del diseño de un objeto virtual de Aprendizaje (ova). [Tesis de maestría, Universidad Nacional de Colombia. Bogotá, Colombia]. http://bdigital.unal.edu.co/39444/1/1186932.2014.pdf

García, B., Coronado, A., y Giraldo, A. (2017). Implementación de un modelo teórico a Priori de competencia matemática asociado al aprendizaje de un objeto matemático. Revista de Investigación, Desarrollo e Innovación, 72), 301-315. 
https://revistas.uptc.edu.co/index.php/investigacion_duitama/article/view/6072

Gutiérrez, D. (2017). Buenas prácticas desde la percepción de los estudiantes de la licenciatura en educación para el medio indígena. Educación y Humanismo, 20(34), 258-270. https://doi.org/10.17081/eduhum.20.34.2869

Hernández, R. Fernández, C., y Baptista, M. (2014). Metodología de la investigación (Sexta ed.). México: McGrawhill. http://observatorio.epacartagena.gov.co/wpcontent/uploads/2017/08/metodologia-de-la-investigacion-sextaedicion.compressed.pdf

Instituto Colombiano para el Fomento de la Educación Superior, Icfes. (2014). Lineamientos para las aplicaciones censal y muestral 2014. https://www.dane.gov.co/files/sen/lineamientos/DSO_030_LIN_10.pdf

Lepe, E. M., \& Jiménez, M. L. (2014). Project-based learning in virtual environments: a case study of a university teaching experience. International Journal of Educational Technology in Higher Education, 11(1), 76-90. https://educationaltechnologyjournal.springeropen.com/articles/10.7238/rusc.v11i1 .1762

Londoño, L. (2017). Comprensión de las medidas de tendencia central, en los niños de grado tercero, cuarto y quinto, utilizando como estrategia el censo en la escuela. [Tesis de maestría, Universidad Tecnológica de Pereira, Pereira, Colombia]. http://repositorio.utp.edu.co/dspace/bitstream/handle/11059/8143/3727L847.pdf?s equence $=1$

López-Roldán, P., y Fachelli, S. (2016). Análisis de varianza. En Metodología de la Investigación Social Cuantitativa. Bellaterra, Espanya: Universitat Autònoma de Barcelona. http://ddd.uab.cat/record/263568

Masmitja J. (2013). Rúbricas para la evaluación de competencias. https://www.aehe.es/wpcontent/uploads/2015/09/rubricas_evaluacion_competencias.pdf

Melo, H. (2017). Las tic como herramienta en el proceso de la comunicación en la enseñanza de la estadística. [Tesis de maestría, Universidad Nacional de Colombia, Medellín, Colombia]. http://bdigital.unal.edu.co/62145/1/97471152.2017.pdf

Ministerio de Educación Nacional. (1998). Lineamientos Curriculares en Matemáticas. Bogotá, D.C: Cooperativa Editorial Magisterio.

Ministerio de Educación Nacional. (2006) ${ }^{a}$. Estándares Básicos de Competencias en Matemáticas. Bogotá, D.C: Cooperativa Editorial Magisterio. 
Ministerio de Educación Nacional, (2006) $)^{b}$ Competencias. https://www.mineducacion.gov.co/1759/articles17596_archivo_pdf_desarrollocomp etencias.pdf

Ministerio de Educación Nacional. (2016). Derechos Básicos de Aprendizaje. Bogotá, D.C: http://aprende.colombiaaprende.edu.co/sites/default/files/naspublic/DBA_Matem\% C3\%A1ticas.pdf

Muñoz-Repiso, V., y Gómez-Pablo, V. (2017). Aprendizaje Basado en Proyectos (ABP): evaluación desde la perspectiva de alumnos de Educación Primaria. Revista de Investigación Educativa, 35(1), 113-131. http://dx.doi.org/10.6018/rie.35.1.246811

Pacheco, W., Parra, K. \& Vargas, L. (2015). Camino al mejoramiento de la comprensión de las medidas de tendencia central en grado $9^{\circ}$ de la ENSDB (Escuela Normal Superior del Distrito de Barranquilla). Revista Colombiana de Matemática Educativa 1(1b). 102-106. http://www.ojs.asocolme.org/index.php/RECME/article/view/217

Peña, C., y Acosta, L., (2017). El aprendizaje por proyectos en el tratamiento de la Estadística durante la formación pregraduada de profesores de Matemática. Mendive. Revista de Educación, 6-20. http://mendive.upr.edu.cu/index.php/MendiveUPR/article/view/942/pdf

Pérez, R., García, J. L., Gil, J. A., y Galán, A. (2009). Estadística Aplicada a la Investigación. Madrid: Pearson Educación http://portal.uned.es/EadmonGuiasWeb/htdocs/abrir_fichero/abrir_fichero.jsp?idGu ia $=73614$

Real, M. (2011). Las TIC en el proceso de enseñanza y aprendizaje de las matemáticas. https://personal.us.es/suarez/ficheros/tic_matematicas.pdf

Rodríguez-Cepeda, R. (2016). Aprendizaje de conceptos químicos: una visión desde los trabajos prácticos y los estilos de aprendizaje. Revista de investigación, desarrollo $e$ innovación, $ス 1)$, 63-76. http://www.cuadernosdepedagogia.com/content/Documento.aspx?params=H4sIAA AAAAAEAO29B2AcSZYIJi9tynt_SvVK1B0oQiAYBMk2JBAEOzBiM3mkuwdaUcjKasqgcpIVmVdZhZAzO2dvPfee-999577733ujudTif33_8_XGZkAWz2zkrayZ4hgKrIHz9-fB8_IorZ7LOnb3bo2dv99N77i-8zOumqJaf7e3s7u_u7nyKD4rz66fV9M31Kv_sPCub_Bfmk6p6G7z35v2_w8RpcvpUQAAAA $==$ WKE

Rodríguez, I. R., y Vílchez, J. G. (2015). El aprendizaje basado en proyectos: un constante desafío. Innovación educativa, (25), 219-234. https://doi.org/10.15304/ie.25.2304

Salcedo, R. (2018). Unidad didáctica para la enseñanza de Probabilidad, mediada por un 
Ova, orientada a un colegio rural del municipio de Paipa. [Tesis de maestría, Universidad Pedagógica y tecnológica de Colombia. Duitama, Colombia].

Sistema Integral de Evaluación SIEE (2019). Institución Educativa Técnica Francisco José de Caldas. http://www.ietecnicaldas-socotaboyaca.edu.co/tema/politicas-ylineamientos

Siswono, T., Hartono, S., \& Kohar, A. (2018). Effectiveness of Project Based Learning in Statistics for Lower Secondary Schools. Eurasian Journal of Educational Research, (75), 197-210. https://files.eric.ed.gov/fulltext/EJ1181463.pdf 